InOdia $\quad \begin{aligned} & \text { InMedia } \\ & \text { The French Journal of Media Studies }\end{aligned}$

7.1. $\mid 2018$

Visualizing Consumer Culture

\title{
The Historical Characters of American Girl dolls: Spectacle and Visual Culture as Agents of Consumerism
}

Anne Lesme

\section{(2) OpenEdition \\ Journals}

Electronic version

URL: http://journals.openedition.org/inmedia/1055

DOI: 10.4000/inmedia.1055

ISSN: 2259-4728

Publisher

Center for Research on the English-Speaking World (CREW)

\section{Electronic reference}

Anne Lesme, «The Historical Characters of American Girl dolls: Spectacle and Visual Culture as Agents of Consumerism », InMedia [Online], 7.1. | 2018, Online since 20 December 2018, connection on 08 September 2020. URL : http://journals.openedition.org/inmedia/1055 ; DOI : https://doi.org/10.4000/ inmedia.1055

This text was automatically generated on 8 September 2020

(c) InMedia 


\title{
The Historical Characters of
} American Girl dolls: Spectacle and Visual Culture as Agents of Consumerism

\author{
Anne Lesme
}

A sincere thank you to Mary Boyington for her contribution.

Three mini dolls Amerian Girl BeForever, Addy Walker (1864), Samantha Parkington (1904) and Julie Albright (1974).

(c) photo annelesme 


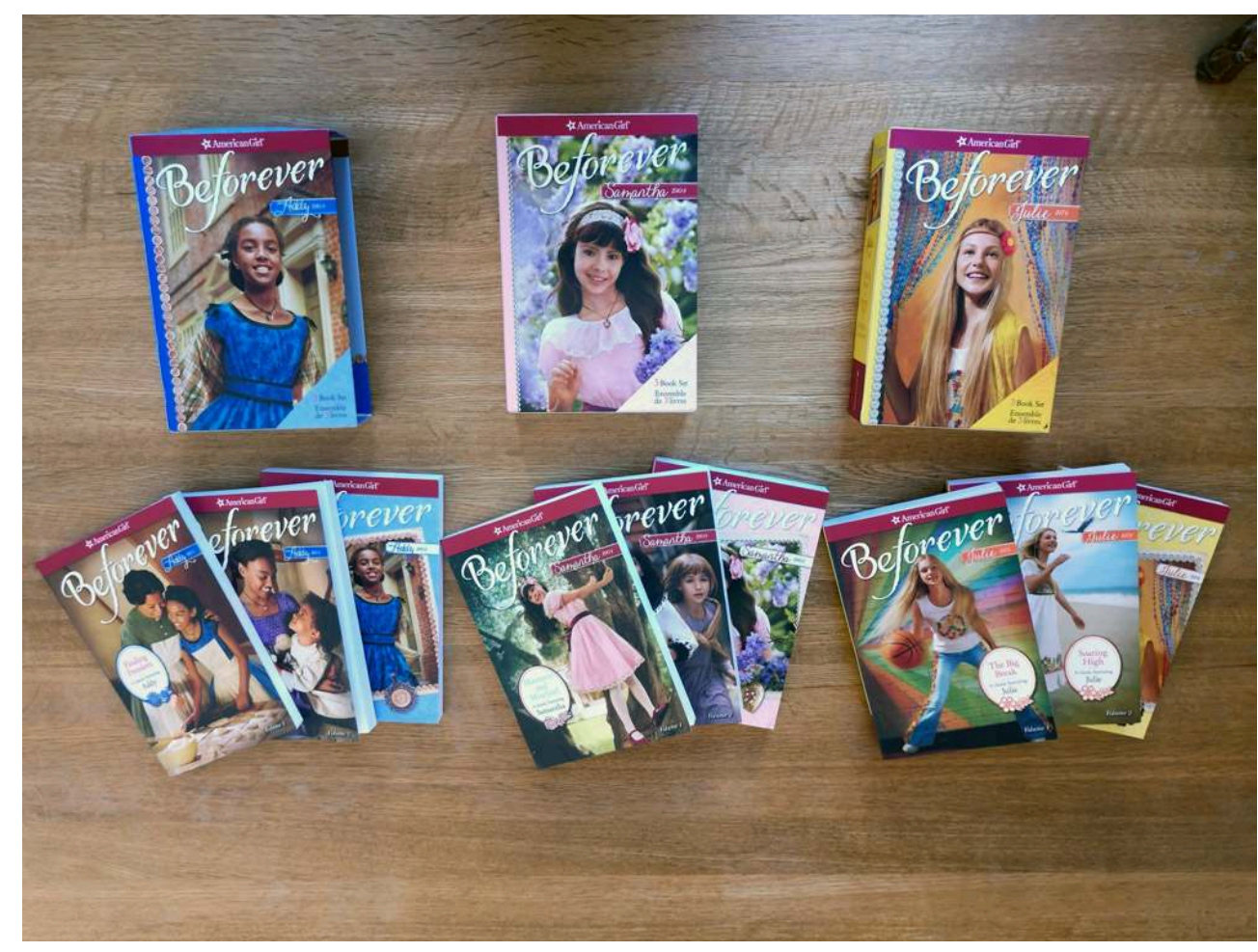

The accompanying books for the 18 inch dolls Addy, Samantha and Julie,

(C) photo annelesme

\section{Introduction}

1 If "spectacle" is this "mise hors-la-loi de l'histoire" described by Guy Debord", how have the historical characters of the doll collection American Girl been so spectacularly successful in the United-States? And how is American history visually present in the dolls, the corresponding books, and the various accompanying merchandise?This paper critically explores the visual artifacts used in the marketing strategy of American Girl dolls-founded by Pleasant T. Rowland in 1987, then bought by the American toy maker Mattel in 1998 until today-to create a product most appealing to young girls, as well as their mothers, who are specifically targeted. Photography, fashion, accessories, advertising, and increasingly,the Internet are at the same time part of the products sold, and tools of visual culture used to promote and display the products.I focus on the post-Victorian Progressive aristocrat Samantha ("a kindhearted girl in 1904 who won't let 'proper' society stop her from helping others"), the groovy seventies Julie ("an upbeat San Francisco girl who stands up and fights for what's right in 1974") and the Civil War Addy ("a courageous girl who escapes slavery and keeps her family strong in 1864"). ${ }^{3}$ I analyze these three dolls to argue that American history is partly used as a (pre)text to consume more and more merchandise, to the point that the initial textnamely, the books that come with the dolls-paves the way for a new world, one that is imaginary, entirely centered on the visual desire of the little girl, making spectaclea real "driving force"(force agissante)as put by Guy Debord. ${ }^{4}$

2 The version of history offered in the historical fictions have previously been studied by scholars who underline their ideological nature, as materialism, female passivity and 
dependence are being reinforced. ${ }^{5} \mathrm{Fred}$ Nielsen, in his analysis of the historical accuracy insists on certain anachronisms and omissions. ${ }^{6} \mathrm{Feminist}$ readings have been carried out as well: Sherrie A. Inness ${ }^{7}$ emphasizes the aim of the company to provide heroic role models for girls, ones that are more diverse and empowered, a departure from the superficiality (Barbie) or sweet maternity of many other dolls. But she also argues that the ideas conveyed about how girls should act and look remain traditional, and that gender stereotypes have not been challenged. She also denounces the eurocentrism of the dolls ("American-centric attitude") ${ }^{8}$ and their tendency to under-represent racial diversity, as well as the superficial and sometimes stereotypical way to address poverty. Elizabeth Marshall underlines that what is at stakes is the pedagogy of consumption rather than a desire to empower girls through history lessons. Finally, the role of nostalgia was recently analyzed by Molly Rosner, who argues that the "company uses nostalgia as a tool to foster consumer devotion to the brand, constructing a powerful narrative of revisionist history to sell idealized pasts and childhoods." ${ }^{\prime \prime}$

What I am mostly interested to explore in this article is the materiality of the objects and how they visually speak to the consumer, particularly following the changes initiated by Mattel when rebranding the collection. The work of French sociologist and philosopher Jean Baudrillard ${ }^{10}$ contributes to the analysis of the different values of the products sold and to their social significance in a capitalistic society driven by consumption. With The Society of the Spectacle ${ }^{11}$ and Comment on the Society of the Spectacle ${ }^{12}$,Guy Debord goes further with the concept of "Spectacle", not only conceived as the reign of representation and the way it has replaced an authentic social life, but also as "a social relation between people that is mediated by images" in the mass media, advertising, and popular culture. ${ }^{13}$ His critique of the mass media and consumer culture, culminating into "the decline of being into having, and having into merely appearing"guides my analysis. ${ }^{14}$

\section{Selling an "image of girlhood" through history}

\section{History of the line: from the Historical dolls to BeForever}

American girl dolls were first released forty years ago by the Pleasant Company. The dolls were $46 \mathrm{~cm}$ (18 inches) and portrayed eight- to eleven-year-old girls growing up in various periods of American history, thus representing a specific era: Kirsten Larson (pioneer, 1854), Samantha Parkington ("Victorian"15, 1904) and Molly McIntire (Second World War, 1944) were the first to be produced; then came Colonial doll Felicity Merriman (1774) and Civil War doll Addy Walker (1864). Later on, other historical characters were released, among them Julie Albright $(1974)^{16}$, with each doll representing a specific era. The aim was to make the dolls not only fun, but educational. The dolls came with books narrated from the American Girls' (aka the dolls') viewpoint; the commercial release also included a variety of related clothing and accessories-for both dolls and girls. According to Rowland, her goal was to put "vitamins in the chocolate cake". ${ }^{17}$ The products were sold exclusively by mail order and the catalogue was essential in the marketing strategy of the brand. In 1995, the line was expanded to include characters and stories from contemporary life: American Girl of Today was released, then renamed and rebranded in 2006 to Just Like You and changed again in 2010 to Truly Me. These dolls are fully customizable, each detail can be 
personalized, including the color of their skin and their type of hair, allowing consumers to create a doll in their image.

In 1998, when Rowland sold the company to Mattel-the American multinational toy manufacturing company whose products and brands include, among others, Barbie and Fisher Price-many fans feared that the Historical line of American Girl would be neglected in favor of the contemporary one. The brand explicitly "archived" a number of historical dolls (such as Samantha, Cecile, Caroline, Kirsten, and Molly) and discontinued their sales, taking them off the market and confirming the apprehension of fans who protested. Subsequently, their values increased in the hands of collectors.

But even though Mattel's priority was the contemporary line-which fosters the trend of an increasing identification of the consumer with the doll, as shown by the line Truly $\mathrm{Me}$-the company has continued to promote new dolls in the historical character line. Indeed, in 2014, the line underwent a complete re-branding and was renamed BeForever. Whatever the profits generated, it seemed to be a way for American Girl to reaffirm that this line remained "the brand's centerpiece". ${ }^{18}$ Such a remarketing operation was designed to make the historical characters relevant to a new generation among the target audience and some of the dolls previously "archived" returned to sales with Samantha being the first. Very recently, in 2016 and 2017 respectively, Mattel released Melody Ellison (who lives in1964), the third African-American character of the brand (after Addy and Cécile) and Nanea Mitchell (living in 1944), the first Native Hawaiian character..$^{19}$ In doing so, the brand was addressing the criticism that it had previously underrepresented girls of color, as the only doll of color was an African-American character who was a former slave.

7 If the dolls' creator and manufacturers have claimed how keen they were, and are, on selling a product with pedagogical virtues, many scholars have underlined that what was increasingly sold was "an image of girlhood, a 'lifestyle' rather than a single product". ${ }^{20}$ Hence my focus on "how girlhood is sold and marketed within the materials for consumption"21 and how the two companies have appropriated the tools of visual and material culture to promote and display the products, in other words, how they have visually retained the identity of the brand, based on the promise "to entertain and educate"22.

\section{From history to universalism: neutralizing History for profit?}

8 It appears that the strategy of the brand has come to reflect what Elizabeth Marshall calls a "pedagogy of consumption" ${ }^{23}$,as much as the lessons of American history that were to be conveyed at the origin of the manufacturing of American Girl, all the more so that the importance of the books has tended to decrease. For Rowland, a former elementary school teacher, the six accompanying books sold with the dolls were essential to the pedagogical virtue of the toy. They were intended to be the backbone of the educational materials conceived by the founder. The educational goal was core to the brand and the child was supposed to learn American history through reading and playing-the dolls and the books were thus inseparable.

When the line was rebranded BeForever, the six original books of the central series were bundled into two volumes along with a Journey series with a modern-day girl travelling back in time into the different eras of the line, at the expense of the numerous illustrations by renowned artists which were all removed from the new edition. The 
books were no longer the main medium for visual contents. As for the edition's cover picture, the drawings or paintings previously used were now replaced by more realistic photographs, with a contemporary model wearing a historical outfit. ${ }^{24}$

One of the core sections of the book referring to history and entitled explicitly "Looking Back" was renamed "Inside Addy's world" or "Inside Julie's world", with a central focus on the character whose adventures are narrated. It was reduced to two pages per volume, while six pages were previously dedicated to this section. Despite the reduced content, these two pages continue to combine various factual details about the way of life at the time and feature the major debates of the era. The initially intended goals of the section are respected but its significance is reduced. the major debates of the era, presented but with very small specific highlights. "Inside Samantha's world" for instance, insists on the role of fashion at the turn of the $20^{\text {th }}$ Century shortening of the skirts or removal of corsets-on urbanization and progress in transportation, as well as on the appearance of the first household appliances. The major issues addressed are the Civil War and slavery in Addy's story, child labor and women's suffrage in Samantha's, or sex discrimination and the environment in Julie's. The previous format nonetheless contained more precise details regarding the main topic of the books. In "Inside Samantha's world", the role of Jane Addams's during the Progressive Era is no longer mentioned. The innovative social, educational, and artistic programs of the settlement "Hull House" she promoted was suppressed.

By erasing such detailed historical information, the message of the books tends to be more universal. The promotional catch phrase of BeForever on the homepage of the website of the line is explicit, as the internet user can read: "Historical characters: timely stories, timeless lessons". ${ }^{25}$ This strategy echoes Julie Rubin's analysis of the brand's stores:"anything that may make the girl different is treated as entirely standard here" ${ }^{26}$.

13 Whatever the period envisioned, the same common core values are conveyed by the books: courage, compassion, love, friendship, and tolerance. Such values herald the power of universality, which is promoted in many other visual artefacts. For instance, the conclusion offered to the reader in Inside Julie's world, the girl of the seventies, is likely to de-emphasize the specificity of the historical period, as the final sentence of the last version of the book indicates:

While the country still faces serious problems, Americans of all ages, races, abilities and political viewpoints continue to tackle these issues [the desire to make the world a better place] with optimism and creativity. They don't always agree with one another, but they usually share the same basic goal-to make their country truly a place of justice, freedom, and equality. ${ }^{27}$

14 As evidenced by the sentence above, Mattel's recent move to elevate the book's status may support the argument that history does matter for the brand; incidentally, several scholars researching the American Girl have even insisted on the importance of the historical fiction books in downplaying consumerism, even though the brand is obviously not based on non-profit education. But this argument does not apply to the mini-dolls line. Indeed, a smaller version of BeForever (6.5 inches) is sold for $\$ 25$ whereas the full-size doll (18 inched) costs \$118. A unique copy of the book is included with the mini-doll, whereas the full-size dolls are sold with a series of three books. But what is it worth? 
To be more precise, each doll comes with an abridged copy of the first volume. The tiny book raises the questions of the manufacturer's intent. First, one must examine the exact status of an object that is, in all practical sense, not intended for comfortable reading-the size of the font is a tiny Times New Roman 6.As for the size of the book itself, we are now far from the line's original full-size books and stand-alone size is contrasted by the new format that hardly measures more than an ID photo at $2.5 \times 1.7$ inches $(6,4 \times 4,3 \mathrm{~cm})$. The player can also examine what remains of the discussion between Samantha's grandmother and her aunt Cornellia on Women's suffrage for example. In the original book, one can read:

Grandmary: Those suffragists are making spectacle of themselves. They should stay

at home where ladies belong. (vol.2, 27)

Cornellia: The time has come for us to speak out. We must stand up for what we

believe is right!" (...) "We must make up our own minds. The time has come to

change the old ways." Women must vote! (vol.2, 42)

Grandmary: I've said that I am too old to change my ways, but I've changed my mind today (....) then I think women should vote. The time for change has come. (vol.

2, 46)

But a careful examining the small book reveals that the chapter in which this discussion occurs is not even reprinted as only five chapters out of fifteen are printed from the first volume. The discussion on women's suffrage occurs on the second volume and is therefore omitted from the small book. Whatever the size, the opinions on how books are triggering the purchase of the dolls and a range of merchandise differ, which leads to a deeper understanding of what is at stake in terms of crossmarketing, as far as the visual and material culture of the products sold are concerned. Whatever the sizes of the doll and the accompanying book(s), opinions on how instrumental the books are in triggering the purchase of the dolls and the range of merchandise differ. To better understand the mechanism at stake, we will further explore the culture of consumption of the band.

\section{Consumerism and material culture, "l'objet-passion" (Baudrillard)}

\section{Visual imagination as trigger for material purchase}

\section{The books}

17 Through the books and the additional merchandise surrounding the dolls, Mattel is involved in in-house cross-marketing: each product considered separately contributes to the promotion of the other. The visual imagination of the little girl is key to this process which encourages the identification of the girl with the character. As such, the historical books are efficient instruments of advertisement. Indeed, the consumer (the girl) is subtlety driven to long for the accessories of the story and the doll which comes with the books. The aim of the brand is to create an emotional connection between the girl and the doll, and then to physically experience the world in which she is immersed in the book. Subsequently, buying the main products is a way to recreate the atmosphere of the book. For example, the readers are exposed repeatedly to "homemade" objects that they can purchase as well, like a necklace which originally belonged to Addy's grandmother, or the Egg chair in which Julie sits. Sometimes the plot even focuses on "a longing for material goods that have been imbued with 
sentimental value", ${ }^{28}$ like Samantha, who yearns for an expensive doll. This mise en abyme is very telling in terms of consumption, as it is a way for the little girls "to 'own' and consume both culture and history" as Molly Rosner underlines. ${ }^{29}$

Even though several accounts are stories of deprivation, one has to admit that there is a real tension between the profusion of products available in the catalogue and the limited products the books can promote. For example, two dolls live in particularly deprived eras: Kit during the Great Depression and Addy, former slave, at the end of the $19^{\text {th }}$ Century. They possess very few items in their respective books. Nevertheless, the objects sold in each line are as expensive as the ones for the other dolls. It is not surprising that one of the key ways the consumers "related to American Girl is through the material culture they collected or coveted" 30 .

Jean Baudrillard argues that "every object has two functions: one is to be used, the other is to be owned or possessed". ${ }^{31} \mathrm{He}$ describes what he calls l'objet passion means for a child and the age bracket he mentions is exactly the target of the American Girl dolls consumers: "Tidying, ordering, handling are the most rudimentary way for controlling the outside world in children. The active phase of collecting seems to be seven to twelve years old, during the latency period, between prepuberty and puberty" ${ }^{32}$ The brand understands this and the catalogue ${ }^{33}$, the stores and the girls' practice with their dolls perfectly match this desire to collect, organize, file, and handle different items, namely the dolls and the multiple clothes, accessories and furniture that go with it. Indeed, these are not by-products in the traditional sense of the term, since American Girl (AG) consists of a series of merchandise; and a collection combines both older dolls as well as contemporary ones and associated products. The market of adult collectors is hard to quantify but it exists, and it is often part of the intergenerational feature of the consumers of the product. The market of adult collectors is hard to quantify, one must not deny the intergenerational aspect of the consumers, mothers and now grandmothers being highly involved in the purchasing and collection of merchandise.

\section{The catalogue, the first temple of consumption}

20 As previously noted, the catalogue was initially the principal marketing strategy of the brand. For many years, AG products were available only via mail order catalogue. It allowed the company to have full control over the display of the doll within an imaginary environment made of different outfits, accessories, and furniture, as if on a stage. The two double-pages dedicated to Samantha and Julie in 2016 show at once the proclaimed identity of the girl:

I'm Samantha, I've never met a tree I couldn't climb, a rule I couldn't ruffle, a friend I couldn't help. I'm all heart and always ready to lend a hand to somebody in need. I'm Julie Albright, I like school and hanging out with friends and I play on the basketball team. The boys' basketball team, I'll take on any challenge. Sometimes I take on too much. But that's ok-everything will turn out groovy in the end. I know it. $^{34}$

21 A diversity of accessories, furniture and outfits can all be purchased. The three books are also displayed but occupy only one-sixteenth of the second page, whereas, as far as Julie is concerned, the famous Egg chair set of the 1970s, inspired by Swedish designer Arne Jacobsen, occupies two thirds of the third page dedicated to the doll. The price in US dollars is written in a tiny but bold character on the last page: $\$ 100$ chair. The doll is now sold for $\$ 115$ US dollars. ${ }^{35} \mathrm{Julie}$ seems to be the most popular in the BeForever 
line, but the sales figures of the brands are unavailable, and when the executives are questioned, they remain secretive on this matter.

Two studies were conducted which deconstruct the philosophy promoted by the brand and demonstrate the consumerism at stake. In the 2000s, over the course of five years, Elizabeth Marshall conducted semi-structured interviews with young women who played with AG dolls. She asked them what they remembered and were attracted to most about the product line. Molly Brookfield, another scholar, conducted her survey with former AG players via a social network, starting with Facebook, then continued the discussion and correspondence with members of her panel by email: any interviewees, if not most, underlined the role played by the materiality of the objects. Women favored a doll based on her clothes, accessories, or physical appearance rather than her personality or story: "It was the clothes that I found the most appealing"36.

The clothing line seems to be the main focus for the girls, far from educational concerns or references to the historical identity of the dolls. The progressive-minded Samantha, who raises the issue of child labor and women's right to vote, is never mentioned. She has always been very popular for her beauty and remains so, as Emily emphasizes: "I really liked Samantha. She was pretty and had girly clothes and I'm pretty sure this was $90 \%$ of her appeal. The sailor suit she wore in the summer book hot damn". ${ }^{37}$ The same process is at work with Addy, the former slave, who is not remembered for the hard life she endured and the cause she defended, but for her outfit. Bethany comments: "I liked Addy and I remember liking Samantha too because they had so much stuff like all the extra stuff that came with them and not a lot of girls that I knew had them" ${ }^{38}$ To conclude on this point, Julianna explains: "It was a big deal to have the doll...[a]nd if you had multiple outfits and accessories (including the furniture), you were a god among the girls" ${ }^{39}$.The contemplated objects become a status symbol for the girls with financial means to acquire the dolls and the associated merchandise, essentially creating a rift between the girls who have them and those who yearn for possession and representation more than anything else, and particularly more than playing.

Because of its acute knowledge of the young girls market, Mattel introduced a change in the clothing of the dolls and the girls when rebranding BeForever. The dolls are now sold with a new outfit, still linked to their historical belonging, but with a more contemporary style. Above all, following the increasing identification of the girl with her toy, Mattel produced clothing for girls inspired by a historical outfit, but these clothes are not a replica of the dolls'. The child is not wearing a costume but an outfit she feels comfortable in, up to the point that some events are even organized to teach History through fashion. ${ }^{40} \mathrm{As}$ far as the website is concerned, you can click on the clothes "For Dolls" (size 3 to 7) or "For Girls" (size 6 to 20). If the T-shirt, skirt and leggings designed after the fashion trends in Julie's 1970s San Francisco remain popular, the Victorian-style Afternoon Tea Dress inspired by Samantha is no longer available. Nevertheless, there is another use which also contributes to the brand's prestige: it has joined the temple of children and adults who own and create a "collection".

At the end of the 1990s, Mattel shifted the focus of the AG product line away from catalogue sales to retail sales with dedicated stores called "AG Place." The chain of stores in the US and Canada began with the opening of the flagship store in Chicago in 1998 with an impressive structure that included thirty-five thousand square feet spread 
over three stories. Other stores followed, including stores in New York City and Los Angeles as well as a number of smaller boutiques.

\section{American Girl Place}

In these temples of consumption, designed to provoke a strong yearning for possession, rotating stocks, regularly updated, are featured in a museum-like display. Adultsmainly mothers and also grandmothers-are encouraged to purchase the idealized childhood they dream about for their children. Many items are presented on pedestals, some reachable, some unreachable to increase their value, but the boxes below are not missing if you want to buy them, they occupy about two thirds of the space in the store. Historical artifacts are displayed in dioramas to appeal to the sense of collection some children and parents develop.

As stated in Time magazine, "the genius behind American Girl's high-end products is that moms feel good about dropping a lot of cash on low-tech, wholesome Americana". ${ }^{41}$ Thanks to a visit in June 2017 in the Washington D.C.AG place (Tyson Corner Centre), I was able to experience the world created around Julie and her 1970s way of life. Four window displays were dedicated to Julie, featuring her at different moments or in several occasions during the day. In the morning, Julie wakes up (her bed and bedding are displayed on a shelf-\$125), wearing her Zig Zag Pajamas (\$24), she goes to her "Groovy Bathroom" (\$175). She can then brush her hair in front of her Daisy Vanity (\$60) accompanied by her pet rabbit Bunny (\$24); in another showcase, she is featured with another outfit, a Tunic (\$34). Later in the day, when time comes for sport activity, she is a basketball player, and as such, she needs the basketball uniform (\$34) and the accessories to play (\$38). When Julie goes back home for a snack (snack set \$50), she can sit in her famous Egg chair (\$100). Finally, if Julie feels like a little stroll with her two dogs (but the Dog Walking set was out of stock this day June 25, 2017), she can wear her Peasant top outfit (\$32) enhanced with floral accessories (\$24). And to have a chance to possess the complete collection, the young girl can dive into the "Inspired by Julie" wardrobe and buy child-sized Zig Zag Pajamas (\$42), not to mention that many other outfits can be found on the online catalogue.

As evidenced in this long, comprehensive list of accessories and merchandise, parents sometimes push back against overt consumerism, as exemplified in this quotation given by Fred Nielsen as early as in 2002: "The atmosphere is so oppressively commercial, so thoroughly inauthentic, that I had to take a break and walk around outside. (...) American Girl Place pretends to be about sweetness and togetherness, but the real message is: Happiness is a Stuffed Shopping bag". ${ }^{42}$

Nevertheless, AG places are mostly extremely profitable venues where the consumers appear to be very excited. This sense of excitement is made all the more visible through new media and in the digital sphere. Therefore, one can question how instrumental history is in the promotion on those media and the extent to which it is still at the heart of the brand.

\section{Digital products and « mise hors-la-loi de l'histoire » (Guy Debord)}

Many digital media are available (Official AG website, YouTube channel, Facebook, Instagram, videogames; Project Runway ${ }^{43}$, YouTube channels created by Internet users to name a few). Two of these media are favored as they address different targets and 
are produced by different people, the first one being more institutional: the official website targets mainly adults with mothers ${ }^{44}$; and the most popular YouTube channel created by an Internet user, "Chloe's American Girl Doll Channel”, directly targets girls. 45

\section{American Girl, the official website: https://www.americangirl.com//}

31 Today the main vehicle for the institutional communication of the brand is the official American Girl website. The catalogue is mostly available online in a .pdf format and the website enables the brand to offer a wide range of services which go well beyond mere merchandise.

At first sight, the website homepage seems to be open to a wide range of audiences (children and adults), but the user quickly understands that children are not the main focus of the media. Five tabs are displayed at the top of the page: "Shop", "Explore", "Store", "Create your own" and "Who we are". When the user wants to browse a commercial tab (four tabs out of five), the same message appears: "This site is intended for grown-ups only", "Keep going" or "Going back". The seemingly less commercial tab "Who we are" is dedicated to the philosophy of the brand with strong emphasis on the player, the young girl:

We believe in creating girls of strong character. Because character counts.

Facing fears, running into roadblocks, and learning from mistakes? That's life. Responding with optimism and resilience? That's character-the kind we build in girls everywhere, every day through stories and experiences both timely and timeless.

Strong characters. Powerful stories. Trusted advice. ${ }^{46}$

The aim is clearly to convince parents that the doll and its universe are probably the best gift for her education, a very moral model that you can identify with. A mechanism of subscription and rewards relentlessly pushes the user to engage, in one way or another, with the brands' life and profit by repeat shopping, whether online or in the AG places. You can click one of the buttons to allow you to "become an AG Rewards member and earn 25 points today! Join now", or you can "write a review for a chance to win a \$ 100 gift card". You can also "Register now" for the "space camp", signing up "your girl or the whole family". Finally, you can "subscribe today" to the American girl magazine, winner of the 2017 Parent's Choice Silver Award or start adding up "AG Rewards to add up the most inspired perks around".

The "shop" tab contains no surprises, but interestingly enough, the dolls of the BeForever line-the historical characters of the brand-are not presented in a chronological order. Marketing choices are favored to promote a range of dolls, such as the last historical character released or the most popular for instance.

The "store" tab allows the user to discover an extremely diversified range of products or services, depending on the location chosen. On the homepage of the flagship store in Chicago, the motto is explicit:"More than just a store, it's an experience". The website enables parents to plan a vacation around the visit to AG place, from selecting a partner hotel-with a "doll bed to keep when you book an American Girl Package"-to attending a "Tea Party" or making a reservation to a "Doll spa deluxe package" or, more traditionally a "Make her birthday the best yet" starters are described as "scrumptious", the main courses as "marvelous" and the 
desserts as "one of a kind creations". The 9-and-under guest can enjoy a "Truly me menu" (no trace of BeForever menu) for \$19 while her mother (most of the time as shown in the pictures) is ordering a \$25 "Steak Frites" with a glass of wine (Pinot Noir $\$ 8)$ or "Rosé Champagne" (\$8.5) for instance, ending with a "Marshmallow Madness Sundae" (\$9). Then, the Doll Hair Salon is waiting for the doll who, along with her "owner", can also get her ears pierced. The parents can even make a reservation for a "Holiday Doll hair Salon Spectacular" where the girl will learn about "new and exclusive Candy Cane twist hairstyle." ${ }^{48}$

The "Play" tabcan be access freely and is the only one that children can browse alone. Faithful to the pedagogical spirit of the brand at its origin, a whole range of games, quizzes, e-cards are offered to the child who can choose the character he/she wants to focus on. A page is dedicated to each doll of the BeForever line with a variety of interactive media. ${ }^{49}$ Nevertheless, we can notice that the latest digital tools (Apps and Emojis) contains very few or no historical characters. ${ }^{50}$

\section{Chloe's American Doll YouTube channel}

While the official website of the brand is mainly dedicated to adults, YouTube channels are more directly targeting children consumers. Nevertheless, the official channel remains more pedagogical with a wide range of videos ("new webisodes of AG Life, \#AGZCrew, DIY craft videos, hairstyle how-to's, plus product previews, sneak peeks") and it is also used to send the consumer back to the official website as quoted in the short description available: "Stay up to date on our inspiring products and exclusive content by subscribing now! And there's always more to discover at americangirl.com" ${ }^{51}$. Chloe's channel is much more personal and focuses on the collection of the girl who introduces herself as being eleven years old. She is currently much more (maybe fourteen) and she carries on her business at a demanding pace, as she commits herself to posting videos every Wednesday and Saturday. She also has an Instagram account and a website/blog. ${ }^{52}$

While the official American Girl YouTube channel boasts 204,000 subscribers ${ }^{53}$, Chloe's American Doll Channel almost reaches double the amount with 361,000 subscribers. Looking at the number of views reveals similar figures: 78,714,737 views for the official network and 155,209,708 views for Chloe's. ${ }^{54}$

A common feature to both networks is that no category appears to be dedicated to the line BeForever, the videos are mainly organized in chronological order and there is no archive of previous videos; it is possible to organize the display in terms of popularity. Chloe's most popular video has been viewed at least 10 million times and the tenth video has been watched two million times. As for the official channel of the brand, the most popular was viewed 6.5 million times and the second one, two million times.

41 Interestingly enough, the first occurrence of a video portraying a BeForever doll ranks $26^{\text {th }}$ on both channels, "An American Girl Story - Melody 1963: Love Has to Win | Movie Trailer | American Girl" on the official channel (468,890 views) ${ }^{55}$ and "American Girl Doll Julie's Bathroom Unboxing - NEW!" (1,075,964 views) on Chloe's channel. While the latter is exclusively dedicated to merchandising, the former partly deals with history as it is the trailer of a movie dedicated to the African-American Melody Ellison who experienced racism in her life and career. 

2015 (11.42 min), "American Girl doll Samantha travels to Texas" ${ }^{56}$, the supposedly Progressive post-Victorian historical character travels to an amazing resort and enjoys the sun in different swimsuits, Crocs sandals and "she also has a phone, just in case" which, unsurprisingly, is an iPhone. The text sounds highly promotional:

I took my American Girl Doll Samantha with me on a long weekend trip to Texas to see my family. We were at a hotel with a water park called JW Marriott San Antonio Hill Country Resort \& Spa. Samantha joined in on the fun sunbathing and riding inner tubes on the lazy river. If you want to see her pack for the trip, check out this video.

In a more recent 6.40-minute vlog published on 24 February 2018, "Chloe visits The American Girl Place Store" 57 , the now "super excited" teen girl, as she describes herself, visits an AG Place with her friend Luna and their dolls and she shoots it with her constantly moving phone or camera. The first stop is in Julie's section and they have a quick rest inside Julie's Egg chair, with some hippie, then rock music coming through the built-in chair speakers (with the possibility to connect a smartphone or tablet). Julie is met again in her basketball outfit, with the "cute" basket, according to Chloe's comments. After sampling and viewing all of the products, the girls go to the Café to order a meal for themselves and for their dolls. And they end up choosing a doll boycurrently a growing market-before going to the doll hair salon. Throughout the sequence, the girls are laughing and giggling, in state of overexcitement induced by the wide variety of American Girl merchandise.

Wonder, more than nostalgia or a desire for historical knowledge, is the central emotion of these experiences as Molly Rosner seems to confirm: "The past is not the site of shared struggles but an opportunity for personal fulfillment through consumption" ${ }^{58}$ With digital media, this feature is even stronger, to the point that the historical component of the dolls has almost disappeared. When it is dealt with, emotional excitement prevails over any kind of mediation, culminating of the "mise hors-la-loi de l'histoire" 59 (history made outlaw) denounced by Guy Debord, an argument he made before the invention of the Internet invention and within a society that was less capitalistic.

\section{Conclusion}

In the line BeForever, the books dedicated to American History as much as to the adventure of the historical character pave the way for a consumerist experience nourished and reinforced by the spectacle of the goods thanks to three "driving forces" ${ }^{60}$, all the more powerful as Mattel masters the art of cross-promotional techniques. The first one is closely related to a way of mimicking the presentation made in a museum in the retail stores which contributes to personalizing the object and adds to its emotional value as well as the admiration it arouses in the girl. Thanks to the objects sold, the second contributes to meeting the desire of the little girl perfectly, as such objects are conceived to fill her imaginary world and to make her feel they are unique while they are manufactured by the toymaker and marketed to girls and their mothers to increase consumerism. As Beaudrillard puts it, "in this sense, independently from our own practice, the objects are, at any given time, anything else, something deeply related to 
the subject. They are not only a material and resisting body, but a mental enclosure where I reign, something for which I am the meaning, a property, a passion". ${ }^{61}$

Finally, what Baudrillard pinpoints finds its logical extension in the fast and growing role of digital media, the corporate ones managed by the brand and the others sometimes even sponsored by the brand) which put the girl and its visual world at the center of the process, erasing steadily the importance granted to history to the benefit of the personal story of the girl-consumer and contributing to her alienation to the benefit of the contemplated object.

\section{BIBLIOGRAPHY}

\section{Bibliography}

Baudrillard, Jean. Le Système des objets. Paris : Gallimard, 1968.

Debord, Guy. La société du spectacle. Paris : Gallimard, 1992 [1967].

Debord, Guy. Commentaires sur la société du spectacle. Paris: Gallimard, 1988.

McDonald, Megan, Soaring High, A Julie Classic, Volume 2, American Girl BeForever, China: American Girl, 2007-2014.

Morgenson, Gretchen. Forbes Great Minds of Business. New York: John Wiley and Sons, 1997.

Zaslow, Emilie. Playing with America's doll: a cultural analysis of the American Girl collection, New York: Palgrave Macmillan, 2017.

\section{Journal articles}

Acosta-Alzuru, Carolina, and Peggy J. Kreshel. 2002. “I’m an American Girl...Whatever That Means': Girls Consuming Pleasant Company's American Girl Identity.” Journal of Communication 52, $\mathrm{n}^{\circ} .1: 139-161$.

Borghini, Stefania, Nina Diamond, Robert V.Kozinets, Mary Ann McGrath, Albert M. Muñiz Jr., John F. Sherry Jr. "Why Are Themed Brandstores So Powerful? Retail Brand Ideology at American Girl Place.”Journal of Retailing, Volume 85, Issue 3 (September 2009): 363-375.

Brookfield, Molly. "From American Girl into American Women: A Discussion of American Girl Doll Nostalgia", Published (Print), Girlhood Studies (2012): 57-75, http://dx.doi.org/10.3167/ghs. 2012.050105

Diamond, Nina, John F. Sherry, Jr., Albert M. Muñiz, Jr., Mary Ann McGrath, Robert V. Kozinets, Stefania Borghini. "American Girl and the Brand Gestalt: Closing the Loop on Sociocultural Branding Research." Journal of Marketing, vol. 73, No. 3, (May 2009): 118-134.

Marshall, Elizabeth. "Consuming Girlhood, Young Women, Femininities, and American Girl”, Girlhood Studies 2, n 1 (2009a)/ 94-111.

Nielsen, Fred. “American History through the Eyes of the American Girls”, Journal of American and Comparative Cultures 25, $\mathrm{n}^{\circ} .1-2$ (2002): 85-93. 
Rosner, Molly. "The American Girl Company and the Uses of Nostalgia in Children's Consummer Culture." Jeunesse: Young People, Texts, Cultures, Vol 6.2 (2014): 35-53.

\section{Book chapters}

Inness, Sherrie A. “'Anti-Barbie': the American Girl Collection and Political Ideologies.”, ed. Delinquents and Debutants: Twentieth-Century American Girl's Cultures. New York and London: New York University Press, 1998.

Marshall, Elizabeth. "Marketing American Girlhood." Rethinking Popular Culture and Media, edited by Elizabeth Marshall and Özlem Sensoy (2009b): 129-135.

\section{Newspaper articles}

Rawe, Julie, “Dolls with a Past,"Time, Dec.03, 2003.

Rosner, Molly, “American Girl: How Radical Can a \$ 105 Doll Be?” Huffington Post, June 26, 2013.

Rubin, Julia, “All Dolled Up: The Enduring Triumph of American Girl, How does a brand be everything to every girl?", Jun 29, 2015,

https://www.racked.com/2015/6/29/8855683/american-girl-doll-store<accessed on July 26, 3018>

Salkin, Allen, “American Girl's Journey To the Lower East Side”, The New York Times, May 24, 2009.

Schiller, Amy, “American Girl Aren’t Radical Anymore”, The Atlantic, April 23, 2013.

\section{Websites}

American Girl, https://www.americangirl.com/<accessed on November 10, 2018>.

Homepage BeForever, American Girl. https://www.americangirl.com/shop/ag/

beforever<accessed on November 10, 2018>.

American Girl Catalog, Summer 2016.

\section{ENDNOTES}

1. "force agissante », Guy Debord, Commentaires sur la société du spectacle, Paris : Gallimard, 15.

2. Guy Debord, Commentaires sur la société du spectacle, 25

3. https://www.americangirl.com/intro2ag/pages/historical_characters.html<accessed on July 2, 2018>

4. « force agissante », Guy Debord, 15

5. Acosta-Alzuru, C. \& Lester Roushanzamir, E. (2003)."Everything We Do is a Celebration of You!": Pleasant Company Constructs American girlhood. The Communication Review, 6(1), 45-69

6. Nielsen, Fred. "American History through the Eyes of the American Girls", Journal of American and Comparative Cultures 25, $\mathrm{n}^{\circ} .1-2$ (2002): 85-93.

7. Inness, Sherrie A. “'Anti-Barbie': the American Girls Collection and Political Ideologies.”, ed. Delinquents and Debutants: Twentieth-Century American Girl's Cultures. New York and London: New York University Press, 1998.

8. Inness, Sherrie A. “'Anti-Barbie': the American Girls Collection and Political Ideologies.”, ed. Delinquents and Debutants: Twentieth-Century American Girl's Cultures. New York and London: New York University Press, 1998: 176.

9. Molly Rosner, "the American Girl Company and the Uses of Nostalgia in Children's Consummer Culture", Jeunesse: Young People, Texts, Cultures, Vol 6 (2014): 36. 
10. The System of Objects, For a Critique of the Political Economy of the Sign, and the Consumer Society, 1968.

11. 1967

12. 1968

13. Guy Debord, La société du Spectacle, 4 .

14. Guy Debord, La société du Spectacle, 9.

15. This name is commonly used but is actually not accurate, the Edwardian era would be more accurate.

16. Kaya, 1764; Caroline Abbott, 1812; Josefina Montoya, 1824; Cecile Rey, 1853; Rebecca Rubin, 1914; Kit Kittredge, 1934, Maryellen Larkin, 1954, Julie Albright, 1974.

17. Gretchen Morgenson, Forbes Great Minds of Business (New York: John Wiley and Sons, 1997), 125.

18. Julia Rubin, "All Dolled Up: The Enduring Triumph of American Girl, How does a brand be everything to every girl?", Jun 29, 2015,

https://www.racked.com/2015/6/29/8855683/american-girl-doll-store<accessed on July 26, 2018>

19. Nanea is the first Native Hawaiian Historical character to be released; she represents the 1940s-specifically Hawaii's role in World War II.

20. Elizabeth Marshall, "Consuming Girlhood, Young Women, Femininities, and American Girl", Girlhood Studies 2, n¹ (2009a): 97.

21. Elizabeth Marshall, "Consuming Girlhood, Young Women, Femininities, and American Girl": 96

22. Inness, Sherrie A. “'Anti-Barbie': the American Girls Collection and Political Ideologies”, 166

23. Marshall, Elizabeth. "Consuming Girlhood, Young Women, Femininities, and American Girl", Girlhood Studies 2, n¹ (2009a) : 95.

24. https://www.americangirl.com/shop/ag/historical-fiction\#facet:\&productBeginIndex: 0\&orderBy:\&pageView:grid\&minPrice:\&maxPrice:\&pageSize:\&contentPageSize:\&, <accessed on October 30, 2018>

25. Homepage BeForever, American Girl. https://www.americangirl.com/shop/ag/ beforever<accessed on November 10, 2018>.

26. "All Dolled Up: The Enduring Triumph of American Girl, How does a brand be everything to every girl?", Julia Rubin, Jun 29, 2015,

https://www.racked.com/2015/6/29/8855683/american-girl-doll-store<accessed on June 26, 2018>

27. Megan McDonald, Soaring Hight, A Julie Classic, Volume 2, American Girl BeForever, China: American Girl, 2007-2014, Volume 2, 201.

28. Molly Rosner, "the American Girl Company and the Uses of Nostalgia in Children's Consummer Culture", Jeunesse: Young People, Texts, Cultures, Vol 6.2 (2014): 45.

29. Molly Rosner, "the American Girl Company and the Uses of Nostalgia in Children's Consummer Culture", 44. Very few scholars disagree with this. We can quote Fred Nielsen for whom "Over and over, the Girls' stories emphasize that friendship, family, and simple pleasures are more important than things", Fred Nielsen, "American History through the Eyes of the American Girls", Journal of American and Comparative Cultures 25, $\mathrm{n}^{\circ} .1-2: 90$.

30. Molly Brookfield, "From American Girls into American Women: A Discussion of American Girl Doll Nostalgia", Published (Print), Girlhood Studies (2012): 66.

31. "Tout objet a deux fonctions: l'une qui est d'être pratiqué, l'autre qui est d'être possédé ", Jean Baudrillard, Le Système des objets, 1968, 104.

32. "C'est chez l'enfant le mode le plus rudimentaire de maitrise du monde extérieur : rangement, classement, manipulation. La phase active de collection semble de situer entre sept 
et douze ans, dans la période de latence entre la pre-puberté et la puberté », Jean Baudrillard, Le Système des objets, 105.

33. See the catalogue, p.23 ad and no mention of history, just to sell the product.

34. Catalogue American Girl, 2016.

35. https://www.americangirl.com/shop/ag/samantha?icid=beforever_landing-2_character_listsamantha-p8\#facet:\&productBeginIndex:

0\&orderBy:\&pageView:grid\&minPrice:\&maxPrice:\&pageSize:\&contentPageSize:\&<accessed on November 10, 2018>

36. Molly Brookfield, "From American Girls into American Women: A Discussion of American Girl Doll Nostalgia": 66

37. Molly Brookfield, "From American Girls into American Women: A Discussion of American Girl Doll Nostalgia": 66.

38. Elizabeth Marshall, "Consuming Girlhood, Young Women, Femininities, and American Girl": 101.

39. Molly Brookfield, "From American Girls into American Women: A Discussion of American Girl Doll Nostalgia": 67

40. http://www.wlox.com/story/33402413/american-girl-dolls-teach-history-through-fashion/ $<$ accessed on November 10, 2018>

41. Julie Rawe, «American Girl: Rise of a Toy Classic», Time, Dec. 3, 2003, http:// content.time.com/time/magazine/article/0,9171,552108,00.html<accessed on November 10, 2018>

42. Jane Eisner, quoted by Fred Nielsen, "American History through the Eyes of the American Girls", Journal of American and Comparative Cultures 25, n.1-2 (2002): 87.

43. Project Runway: season 13, episode 9 (2014).The designers were re paired with a doll (BeForever) and a model and they needed to create a modern and fashionable look. But these dolls already had an outfit and the designer could either use this fabric or they could go somewhere else on their own. They had 30mn to sketch, to talk to their model, to walk around the store.

44. https://www.americangirl.com/<accessed on November 10, 2018>

45. https://www.youtube.com/channel/UC-_tUoyID1rv_ftGBk3tg_Q<accessed on November 10, 2018>

46. https://www.americangirl.com/shop/ag/who-we-are<accessed on July 1, 2018>

47. https://www.americangirl.com/explore/articles/make-her-birthday-the-best-yet/ <accessed on November 10, 2018>

48. https://www.americangirl.com/retail/chicago.html<accessed on November 10, 2018>

49. http://play.americangirl.com/play/beforever/characters/samantha/\#page=home<accessed on March 3, 2018>

50. http://play.americangirl.com/play/apps/, <accessed on July 1, 2018>

51. https://www.youtube.com/user/AmericanGirl/about<accessed on July 1, 2018>

52. http://www.chloesamericangirl.com/ <accessed on July 1, 2018>

53. https://www.youtube.com/user/AmericanGirl/featured<accessed on July 1, 2018>

54. https://www.youtube.com/user/MattMDK/featured<accessed on July 1, 2018>

55. https://www.youtube.com/watch?v=pwokK4E3Zws

56. https://www.youtube.com/watch? $v=1 j 7 \_K V M 1 c L 0 \& t=95 s<$ accessed on November 10, 2018>

57. https://www.youtube.com/watch?v=soybYcfxr7o\&feature=em-subs_digest<accessed on November 10, 2018>

58. Molly Rosner, "the American Girl Company and the Uses of Nostalgia in Children's Consummer Culture", 50.

59. Guy Debord, Commentaires sur la société du spectacle, 25.

60. Guy Debord, Commentaires sur la société du spectacle, 15. 
61. «Les objets dans ce sens sont, en dehors de la pratique que nous en avons, à un moment donné, autre chose de profondément relatif au sujet, non seulement un corps matériel qui résiste, mais une enceinte mentale où je règne, une chose dont je suis le sens, une propriété, une passion. ", Baudrillard, Jean, Le Système des objets, 103.

\section{ABSTRACTS}

This article aims to critically explore the visual artifacts used in the marketing strategy of American Girl dolls-founded by Pleasant T. Rowland (1987), then bought by Mattel (1998)-to create a product most appealing to little girls. Photography, fashion, accessories, advertising, and increasingly the Internet are at the same time part of the products sold and the tools of visual and material culture used to promote and display the products. Focusing on the Progressive aristocrat Samantha, the groovy seventies Julie and the Civil War Addy dolls, I argue that American History is used as a (pre)text to consume more and more merchandise, up to the point that the initial text (the books) paves the way for a new, imaginary world, entirely centered on the visual desire of the little girl, making spectacle what Guy Debord calls a real "driving force". ${ }^{1}$

\section{INDEX}

Keywords: American Girl, dolls, BeForever, consumer culture, girls, History, Internet, Youtube channel

\section{AUTHOR}

\section{ANNE LESME}

Anne Lesme holds a Ph.D. in American studies from Aix-Marseille Université, as well as a degree in Communication and Media studies from the CELSA Sorbonne Paris 4. She is an associate professor of English at Aix-Marseille Universite on the Communication and Multimedia campus (Institut Universitaire de Technologie) in Arles, France. Her research fields are at the crossroads of Childhood studies and Visual studies and her areas of specialization include children and family, art and politics in the United States. Most recently she has concentrated on material culture with the historical characters of the American Girl dolls. 